\title{
The Economics of Peacebuilding: International Organizations for Dealing with Victor and Vanquished
}

\author{
Vera Songwe
}

Peace has been declared at Paris. But Winter approaches. ${ }^{1}$

\section{INTRODUCTION}

The art of peacebuilding is as old as conflict. In a bell curve manner, conflicts began among families, tribes, nations, kingdoms, and clusters of nations, and have since returned to mostly conflict within nations. As conflicts have intensified, so have conflict resolution mechanisms become more sophisticated and institutionalized. Early on, peacebuilding was achieved through unions between the victor and vanquished. This tradition persisted up to nineteenth-century Europe. In some traditions,

This chapter represents the personal views of the author.

V. Songwe $(\varangle)$

United Nations Economic Commission for Africa, Addis Ababa, Ethiopia

(C) The Author(s) 2021

T. McNamee and M. Muyangwa (eds.),

The State of Peacebuilding in Africa, https://doi.org/10.1007/978-3-030-46636-7_3 
especially in the East, the armies of the vanquished were handed over as part of the spoils of war; in others, the territory was annexed. These were well-established practices and constituted what could be termed the etiquette of post-conflict agreements and peacebuilding. The League of Nations, set up by Allied nations following the end of the First World War, was the first global institution set up to handle post-war peacebuilding but also aimed to avoid wars. It met with limited success. Two decades later, following an even bloodier war, its predecessor was created, The United Nations (UN), coupled with two development institutions, informally known as the Bretton Woods institutions (The World Bank and the International Monetary Fund [IMF]).

This chapter draws from the contrasting experiences of the League of Nations and the United Nations to highlight the centrality of economic development to peacebuilding. In doing so, the chapter questions the established sequence of peacebuilding: that only when peace is fully restored can the focus move to economic development. This sequence is clearly contrary to all successful experiences. The chapter argues that the near-dogmatic insistence on this sequential process has, in many cases, such as Guinea-Bissau and Libya, undermined peacebuilding before it has even begun.

Most conflicts are about voice, economic equity, inclusion, and access. Today, J. M. Keynes's words at the end of the Treaty of Versailles discussions_- "peace has been declared at Paris. But Winter approaches"2_-still resonate in many peacebuilding situations as one wonders what is being done to guarantee shared economic development as a weapon of peace. The challenge of responding, to more internal conflicts in the case of Africa, also requires an alternative response that is underpinned by economic imperatives rather than by an established sequence of political negotiations. Most of the conflicts on the continent are, in fact, a direct result of economic deprivation, or inflation-induced conflicts. These require rapid economic peacebuilding solutions.

Section one of this chapter will summarize the activities that led to the signing of the Treaty of Versailles and the big omissions and shortfalls of the Treaty. The second section will look at the peace agreement ending the Second World War and compare and contrast this with the First World War. The third section looks at how the lessons from both agreements have been applied to peacemaking and peacebuilding in Africa, with particular attention to the cases of Guinea-Bissau and Côte 
d'Ivoire. The fourth section concludes with lessons learned for the future of peacebuilding on the continent.

\section{The Treaty of Versailles-An Ambiguous Peace}

In 1920 following the end of the First World War, which cost the lives of more than 20 million people, split roughly equally between military personnel and civilians, the Allied powers came together to agree on the construct of a new world order. In a foreshadowing comment, Keynes lamented the lack of economic vision in the peace plan. $\mathrm{He}$ wrote, the Versailles Treaty "includes no provisions for the economic rehabilitation of Europe...nothing to make the defeated Central Empires into good neighbours... Nor does it promote in any way a compact of economic solidarity." 3 For an economist, the concept of economic solidarity was vital, as it implied jobs and wages-the centerpiece of Keynesian economics.

The peacemakers acknowledged the daunting task that lay before them. "Making peace is harder than waging war," French Prime Minister Georges Clemenceau reflected in 1919 as the victorious powers drew up peace terms, finalized the shape of the new League of Nations, and tried to rebuild Europe and the global order. ${ }^{4}$ For Clemenceau and his colleagues, the prospect of crafting a peace agreement was particularly challenging. Unlike in 1815, when negotiators met in Vienna to wind up the Napoleonic Wars, in 1919 Europe was not tired of war and revolution. Nor had aggressor nations been utterly defeated and occupied, as they would be in 1945. Rather, leaders in 1919 confronted a world in turmoil. Fighting continued throughout much of Eastern Europe even as the Treaty was being crafted.

Then-US president, Woodrow Wilson saw the Paris Peace Conference and resulting Treaty as the beginning of a crusade for humankind. The Treaty was to usher in peace and end all suffering. All the Allied leaders believed that the agreement was just and fitting for both the victor and vanquished. Wilson's League of Nations was meant to create an international community of democratic nations. By providing collective security for one another, they would not only end aggression but build a fairer and more prosperous world.

The victorious Allied forces (Britain, France, the United States, and Italy), both their populations and their leaders, had the right intentions but also wanted to ensure that the vanquished (Germany, Austria, 
Hungary, Bulgaria, and the Ottoman Empire) paid for their aggression. The tension between restoring peace and making the vanquished accountable is ages old and carries within it a delicate balance, one that proposes a just peace while ensuring there is enough deterrent on the part of the aggressors not to exact revenge or feel completely marginalized.

A couple of elements stand out in the Treaty. While it was signed by all the countries, each country negotiated a separate peace deal with the vanquished nations and then the agreements were brought together; in the end, each country tried to exact individual benefit rather than collectively attempt to ensure that the Treaty promoted peace. The French wanted retribution for the destruction of industry and cities on the Rhine and assurances this would never happen again. The British, led by Lloyd George, largely accomplished their main goal, which was to wipe out Germany's High Seas Fleet as a threat to the Royal Navy and protect the British Empire.

Tens of thousands of German civilians died of starvation or malnutrition-related illnesses before Britain finally lifted the blockade once Germany signed the Versailles Treaty, sowing the seeds of German resentment. The Treaty even added to Britain's colonial empire when it (along with France, Belgium, and Japan) assumed "mandates" (colonies in all but name) over colonies the treaty stripped from Germany and the Ottoman Empire. Britain acquired Iraq, Palestine, and Jordan in the Middle East and former German colonies in Africa: South West Africa (present-day Namibia), German East Africa (present-day Burundi, Rwanda, and mainland Tanzania), Togoland (present-day Togo), and German Kamerun (mainly present-day Cameroon).

Wilson's vision for the League of Nations, codified as part I of the Versailles Treaty, was a "general association of nations established to afford mutual guarantees of political independence and territorial integrity of all nations great and small." 5 The pillars of the League were collective security, disarmament, and settlement of international disputes through arbitration. Yet this was based on voluntary participation by League members - essentially relying on "good will." The League of Nations had no standing military force to back up any decision it made, and if a nation disagreed with the League's decision, it could simply "opt out"-as Nazi Germany (1933), Imperial Japan (1933), and Fascist Italy (1937) eventually did when they withdrew from the League after it tried to oppose their aggression. For want of leadership, among other things, the promise 
of 1919 soon turned into the disillusionment, division, and aggression of the 1930s.

Part II of the treaty creating Germany's post-war boundaries (Germany lost 13 percent of its territory and all of its colonies) was seen as dispossessing Germany of its rightful assets and left Germans feeling put upon; part V imposed military restrictions on Germany's armed forces; and part VIII specified war reparations to be paid principally to France, Belgium, Britain, and Italy for civilian damages caused by the German invasion and occupation. The reparations clause was later used by Germany to build national resentment (despite never actually fulfilling their reparation obligations). It provided political fodder for building a new front against the Allied forces.

Glaringly absent from the Treaty of Versailles was any reference to the rebuilding of an economic architecture for trade. The League of Nations focused on the restoration of peace and the protocols for achieving it. The Allied powers stripped Germany of its assets or destroyed trade routes and vessels. There was no attention paid to the economics of peace. Instead, the focus was on the need for Germany to pay reparations and the victors taking over colonies to increase their influence.

The second omission of the Versailles Treaty was that while it purported to end the war there was still fighting going on in Europe further to the East; the appetite for war was not fully quenched. The central theater had been shut down but the continual confrontations in the periphery meant that this could ignite suddenly into a full-blown war again.

The lack of collective enforcement of the Treaty, with the United States not signing onto the final agreement creating the League-an American idea which never found sufficient support at home-weakened the overall peace architecture. The creation of an international body that would help preserve peace and punish those who started wars was lofty in its own right, but many Americans worried the Treaty could inadvertently pull the United States into faraway wars for which it had no direct economic or political interest. The U.S. Congress voted down the Treaty in 1920 leaving the League of Nations without the backing of its founder.

The League and the reparations agreement all proved to be shortlived, as their shortcomings created the opening for renewed aggression in Europe. 


\section{An Economic Peace to Begin All Peace}

In 1939, exactly two decades after the signing of the Treaty of Versailles, Germany invaded Poland, marking the beginning of the Second World War. Unimaginable in 1919, the casualties from the Second World War were almost double that of the First. Over 70 million people are estimated to have died. This is equal to the current population of Ghana, Côte d'Ivoire, and Senegal combined, or 70 percent of the population of Ethiopia. Following the end of the Second World War, the Allied forces sought to correct three fundamental mistakes of the Versailles Treaty. First, the Allies negotiated the peace collectively; second, the role of the United States was more forceful; and third, the Allied powers listened to Keynes and sought to build an economic recovery plan-The European Recovery Program (ERP), otherwise known as the Marshall Plan. ${ }^{6}$

This is the first time in the history of peacebuilding that a full-fledged economic development plan was linked to a peace treaty, with credible and well-funded institutions attached to the plan. The ERP, which began in 1948, was a massive program of aid from the United States to western and southern European countries, aimed at helping economic renewal and strengthening democracy after the devastation of the Second World War.

Sixteen European countries received about US $\$ 14$ billion in aid between 1948 and 1951. Britain received the largest share of this support (US \$3.2 billion); the next largest amounts went to France (US \$2.7 billion), Italy (US $\$ 1.5$ billion), West Germany (US \$1.1 billion), and the Netherlands (US \$1.1 billion). These funds comprised about 2.5 percent of the aggregate national income of European countries over the 4 years. They were 1.2 percent of the total gross national product of the United States. In present-day terms, this would be equivalent to about $\$ 217$ billion for reconstruction. The recovery plan had conditions for the disbursements of aid to address issues of inter alia taxation, budgeting, money, labor markets, and trade. Britain, for example, agreed in 1948 to balance its budget annually, maintain currency reserves at specific levels, and restrict tariffs. The unique element of the ERP was that it was administered entirely by the US government, rather than all the Allied powers. The Economic Cooperation Administration (ECA), 
the US agency that administered aid, used 5 percent of these funds for its in-country administrative costs. The remainder was allocated mainly for economic development, as a result of negotiations between officials of the ECA and each European government. The implementation of the plan benefitted from total bipartisan support.

\section{DIVIDENDS OF THE ECONOMIC Reconstruction Program}

The achievements of the ERP were unparalleled in global economic history. After the First World War, it took seven years to regain the pre-war levels of production in Western Europe. At the end of 1951, three years into the implementation of the ERP, industrial production was 41 percent above pre-war levels, 64 percent above 1947 levels, and well beyond the target originally set for 1952. Agricultural production was 9 percent above pre-war and 24 percent above 1947 levels. Gross national product-the total sum of Western Europe's production of goods and services-had risen 25 percent in real terms in less than 4 years and was 15 percent above pre-war. The transportation system was rehabilitated; electrical output doubled over pre-war levels; steel production doubled between 19471951, far exceeding production by Russia and her satellites; and refined petroleum production quadrupled over pre-war levels.

The gains in agricultural production were less striking but also substantial. Cereal production and bread grains almost regained their pre-war levels, and the output of potatoes, sugar, meat, milk, and oils overshot the targets of the ERP program; in every case, except meat, the results were faster. All other outputs were substantially above the targets and pre-war levels.

The ERP was the largest economic development plan implemented following conflict to restore peace. But it was more than a peacebuilding plan. It was also a vast investment program which guaranteed substantial returns for the United States.

Europe was therefore guaranteed sufficient energy to power and revive its industries; while the United States was able to ensure it was guaranteed supply for its industries and demand for its products. For these objectives to be realized, two conditions had to be met: real incomes had to increase, thus increasing domestic savings; and Europe's current account deficit 
had to be reduced. The peace plan was, thus, at its heart, an economic plan. By 1951 the UK was fully back on its feet and tensions began to emerge between the UK and United States over the former's development trajectory, especially the national health programs the UK sought to adopt. ${ }^{7}$

Christopher P. Mayhew, then Parliamentary Undersecretary of State for Foreign Affairs, speaking in a debate at the United Nations Economic and Social Council, famously said, "We have not the slightest intention of modifying our economic, our social, or our political plans in order to qualify for this aid." Moreover, he argued, the British economic recovery was a result of according priority to "human welfare and social progress," including a "complete national health service" and "public ownership of industry." As economic activity was restored in the UK, tensions between the United States and UK also rose over economic priorities, resulting in the UK finally deciding to opt out of the plan, even as they continued to receive some support from the United States mainly to ensure they were protected from any aggression from Russia. ${ }^{8}$

\section{LESSONS FROM THE ECONOMIC Reconstruction Program}

The lessons from the successful ERP are important for all subsequent peacebuilding efforts globally. Yet, for reasons that are difficult to explain the world has never been able to replicate the ERP as a tool for peacebuilding anywhere else.

The ERP was administered by one country and agency, and rolled out across numerous countries. Essentially, its main objective was to restore and strengthen the economic might of Europe. But, more critically, the ERP did so without sequencing and conditioning initial recovery support on the need for governments to change their fiscal, tax, or monetary policy. Resources were disbursed even as conversations on reforms took place. Even in the case of the UK, where there was growing criticism that it was building a welfare state, the ERP continued to support the country while trying to negotiate a different approach to the UK's domestic policy stance on its social programs. In response to the demand for raw materials from the United States, an important part of the European reconstruction effort was the agreement by the Steel Committee to manage steel 
output in order to control prices to the benefit of the member states. While Europe benefitted from the ERP to recover economically, it was in parallel looking to increase its competitiveness, grow its markets, and strengthen its economic base. To do this, it began to build a European integration plan under French Foreign Minister Robert Schuman. This ultimately led to the creation of the European Union. ${ }^{9}$

As George C. Marshall remarked in his famous "Marshall Plan" speech: "The remedy [to peace] in Europe lies in breaking the vicious circle and restoring the confidence of the European people in the economic future of their own countries and of Europe as a whole. The manufacturer and the farmer throughout wide areas must be able and willing to exchange their product for currencies, the continuing value of which is not open to question." 10 This remains true and pertinent for Africa today.

\section{ECONOMiC DeVElopment and Peacebuilding in Africa}

The preceding sections have summarized the failures and successes of two of the world's most famous peace agreements. The world has not seen destruction on this scale since 1945. However, conflicts persist and the international community in many cases appears incapable of restoring peace. How is it that we have not been able to replicate the ERP? What elements of the plan bear replicating or building on? What ingredients of the plan apply to Africa?

Africa has made considerable progress on the cross-border peace front. At the end of 2019, there were fewer than five active or latent cross-border conflicts on the continent. Post-independence, African countries pledged to respect colonial borders and, with the exception of Sudan/South Sudan, they have largely kept to this promise. The biggest challenge on the continent is that of intra-state conflict. And it is here that peace remains elusive on the continent. Compared to 2005 when there were only 6 countries in active conflict on the continent and 7 armed conflicts, as of 2019 the number of countries with armed conflicts has risen to 17 .

The institutional architecture of the UN and the Bretton Woods institutions as initially conceived does not allow these institutions to play their rightful role in peacebuilding. The continuum from peacemaking, to peacekeeping, to peacebuilding is fragmented and often replete with interests that are not aligned, as was the case in 1919. 


\section{INACTION IN GUINEA-BISSAU}

The case of Guinea-Bissau is instructive. Guinea-Bissau gained independence in 1974. In its short existence, the country has had over 17 coup d'états and as many elections, while the three processes of peace making, keeping, and building have been quite separate and not integrated. Peacemaking is mostly run by the UN; peacekeeping is led by Nigeria and Angola as continental interests dictate; and peacebuilding or economic peacebuilding driven by the Bretton Woods institutions. Unlike post-war Europe, no one single economic power-be it Nigeria, Angola, Portugal, or Brazil-has stepped up to design an economic recovery program that would provide a win-win result for both. The mediation by purely international institutions has proved insufficient and inadequate to restore peace fully.

In addition, like Germany after the First World War, conflict in GuineaBissau has never been fully quelled. A faction of the population still remains equipped for conflict, believing that conflict can and will provide a better shift of power in their favor. More than 20 years after independence, Guinea-Bissau has not been able to establish a viable peace, as the warring factions remain divided along ethnic, and military versus civilian, lines. To date, the international community has been incapable of launching a sizeable and fully inclusive economic recovery plan that benefits all the citizens, akin to the ERP. Rather, these piecemeal attempts have helped to foster divisions and left Guinea-Bissau with one of the highest rates of poverty on the continent despite its rich natural marine, agriculture, and mineral resources.

\section{Côte D'Ivoire-A Success Story}

Though not as successful in magnitude as the ERP, the case of Côte d'Ivoire nevertheless provides some useful pointers on what can be achieved. While the international community, in all its formats, was present in Côte d'Ivoire as the peace was established, following nearly a decade of on-again, off-again civil war in the 2000s, one main economic power, France, decided to underwrite an important part of the peacebuilding plan. As a result, Côte d'Ivoire did not have to wait for years for the economic recovery plan to kick in. Unlike the impressive record within the first four years of the ERP, Côte d'Ivoire did not experience such high rates of growth but nevertheless it registered a consistent 
8 percent growth rate, demonstrating its ability to rebound. A strong Côte d'Ivoire allowed for more French investment in the country, similar to the case of the UK and United States during the ERP.

It is often argued that Côte d'Ivoire was able to rebound because the human capital needed to revive production and industry already existed. The success of the ERP rested, in a similar way, on the availability of skilled labor and strong institutions on which to build a recovery plan. Where institutions are weak, replicating the success of the ERP will prove difficult but not impossible. An important element of the ERP was the recognition of some mutual dependence: the United States needed steel and Europe needed coal. In Côte d'Ivoire, the crisis affected cocoa and chocolate prices considerably and there was a need to stabilize supply and prices in order to minimize global market disruptions. International support for the recovery, as in the case of the ERP, focused on improving the balance of payments so Côte d'Ivoire could rely less on aid and more on Foreign Direct Investment and domestic savings for investment. Côte d'Ivoire was able to quickly rebuild its reserves and increase productivity.

The test of the robustness of the peace will come with the electoral process. The ERP focused on the economic peacebuilding because, even in Germany, broad principles of representative governments had already taken hold, thereby reducing the need to emphasize the "democracy" element.

Overall, despite its shortcomings, Côte d'Ivoire's experience of peacebuilding-relying heavily on an economic recovery program underwritten by a single nation, France, and supported by the UN and the Bretton Woods institutions-has proven successful. Essential to peace in Côte d'Ivoire was the fact that the international community negotiated as one; and internally, strong coalitions for peace were able to form, underpinned by the promise of economic prosperity.

\section{Bleak Outlook for Libya ANd the SAHel}

The Sahel, and Libya in particular, do not present any of the elements needed to deliver a long and lasting peace. Similar to Versailles, the victors individually focused on ensuring they benefitted or protected existing investments in Libya or increased their investments. There was not a collective peace deal aimed at restoring the economic potential of Libya. Second, again like Versailles, while the end of the war was declared, the Libyan factions are not done fighting; as peace was declared in some parts of the country, fighting continued in others, opening the door for renewed escalation of conflict. While Libya's exports could have helped 
to launch a massive ERP, the lack of cohesion within the international community did not allow for such a solution. In addition, unlike in the Second World War where the United States was able to play a strong leadership role, Italy could not take up this role with Libya and the United States was reluctant to do so, creating a leadership vacuum which still persists in 2020 .

\section{CONCLUSION}

The end of the ERP for Europe saw the beginning of the greatest European project: European Integration, which resulted in a stronger and more united Europe, built on clear democratic principles and complemented by principles of macroeconomic prudence and competition and trade openness. With zero interest rates in the West, a young population in Africa and a growing middle class, the economic argument for a peacebuilding partnership with Africa has never been more compelling.

The Marshall Plan was a limited investment that paid incalculable dividends. A situation favorable to American interests was established in Europe. The aid program lifted Western Europe off its knees, launched the American challenge to the Soviet Union, and bolstered the American economy. This last point runs counter to conventional economic wisdom: how could massive government expenditures be a net plus to the domestic economy? The experience of the Marshall Plan shows the answer. Investing to protect prosperity at home generated peace and prosperity abroad, which in turn led to still greater prosperity for the donor. $^{11}$

Africa is a peacebuilding theater. An ERP-type program in some conflict settings could unleash benefits to first movers who dare to take up the challenge.

\section{Key Recommendations}

1. The Economic Reconstruction Program (ERP) is an imperfect but important model. The ERP is hardly the perfect solution to today's conflicts and peacebuilding efforts in the developing world. Nevertheless, it holds the main ingredients for sustained and inclusive peace. The promise of economic prosperity is a clear prerequisite for peace. Over the last 50 years, the developed world has spent huge sums on development aid and the World Bank and IMF, like the 
$\mathrm{UN}$, have been very active. But, the overall results of interventions remain below expectations.

2. Establish a social contract for economic improvement between peacemakers and peacebuilders. Numerous case studies reveal that the absence of a social contract between the peacemakers and peacebuilders on a clear economic improvement plan has been a central factor in the failure of efforts to build peace. Where attention has not been paid to the importance of inclusion, it has led, as in the case of Sudan, to the breakup of the country rather than to the consolidation of the positives and creation of economic inter-dependence benefitting both sides.

3. Committed investment partners and institutions are essential. A successful ERP plan in Africa needs only one of two conditions to exist: adequate institutions, as existed in Côte d'Ivoire, or a deep entrepreneurial culture, together with a committed bilateral investment partner. Where the possibility of reviving or building economic activity exists, where markets for outputs exist to guarantee that aid will turn into an investment in the short run, and countries can move from being aid-dependent to partners, the ERP model holds great promise. Institutions like the UN and the Bretton Woods duo can then serve as honest brokers of these relationships.

\section{Notes}

1. John Maynard Keynes, The Economic Consequences of Peace (New York: Harcourt, Brace and Howe, 1920), 235.

2. Keynes, The Economic Consequences of Peace, 235.

3. Ibid.

4. "Let American Industry March On!" In American Industries (Washington, DC: National Association of Manufacturers, 1918), 19:9.

5. See "Transcript of President Woodrow Wilson's 14 Points (1918)" at https: $/ /$ www.ourdocuments.gov/doc.php? flash=false $\&$ doc $=62 \&$ page $=$ transcript.

6. Forrest C. Pogue, George C. Marshall: Statesman, 1945-1959 (New York, 1989), 207.

7. Daniel M. Fox, "The Administration of the Marshall Plan and British Health Policy," Journal of Policy History 16, no. 3 (2004): 191-211.

8. G. C. Peden, The Treasury and British Public Policy, 1906-1959 (Oxford, 2000), 418. 
9. Helmut Schmidt, "Miles to Go: From American Plan to European Union," Foreign Affairs, May/June 1997, https://www.foreignaffairs. com/articles/europe/1997-05-01/miles-go.

10. George C. Marshall, "Remarks by the Secretary of State at Harvard University" (speech, Cambridge, MA, June 5, 1947), Marshall Foundation, https://www.marshallfoundation.org/marshall/the-marshall-plan/ marshall-plan-speech/.

11. Stephen F. Ambrose, "When the American Came Back to Europe," in "The Marshall Plan: A Legacy of 50 Years," International Herald Tribune, May 28, 1997, 5; see also Michael J. Hogan, The Marshall Plan: America, Britain, and the Reconstruction of Western Europe, 1947-52 (Cambridge: Cambridge University Press, 1987).

Open Access This chapter is licensed under the terms of the Creative Commons Attribution 4.0 International License (http://creativecommons.org/licenses/ by $/ 4.0 /)$, which permits use, sharing, adaptation, distribution and reproduction in any medium or format, as long as you give appropriate credit to the original author(s) and the source, provide a link to the Creative Commons license and indicate if changes were made.

The images or other third party material in this chapter are included in the chapter's Creative Commons license, unless indicated otherwise in a credit line to the material. If material is not included in the chapter's Creative Commons license and your intended use is not permitted by statutory regulation or exceeds the permitted use, you will need to obtain permission directly from the copyright holder.

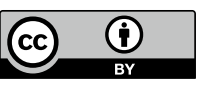

